\title{
Keberadaan Kelompok Jamaah Tabligh dan Reaksi Masyarakat (Perspektif Teori Penyebaran Informasi dan Pengaruh)
}

\author{
Umdatul Hasanah \\ Dosen IAIN Sultan Maulana Hasanuddin Banten
}

\begin{abstract}
Abstrak
Jamaah Tabligh merupakan gerakan dakwah transnasional yang berasal dari India. Di Indonesia gerakan ini mulai muncul pada dekade 1970-an dengan pusatnya di masjid Kebon Jeruk Jakarta. Komunitas ini merupakan kumpulan jamaah yang melakukan aktivitas tabligh. Inovasi mereka dalam berdakwah berdasar pada kitab Faḍāilul 'A'mal, khurūj dan khillah yang merupakan tradisi dakwah mereka. Jaulah adalah cara mereka mengajak dan menyebarkan kebaikan, Amir merupakan sebutan untuk pemimpin mereka. Masjid merupakan basis dakwah mereka. Artikel ini akan mendiskusikan lebih jauh bagaimana keberadaan kelompok Jamaah Tabligh dan reaksi masyarakat dalam perspektif teori penyebaran informasi dan pengaruh. Selain itu, artikel ini juga akan menjelaskan bagaimana inovasi dakwah serta proses penyebaran informasi dilakukan oleh komunitas ini. Tanggapan masyarakat serta dampak kelompok ini juga menjadi bagian dari pembahasan.
\end{abstract}

\begin{abstract}
Jamaah Tabligh is a transnational preaching movement that originated in India. The movement was introduced to Indonesia in 1970s and established Masjid Jami' in Kebon Jeruk Jakarta as its headquarters. The members of Jamaah Tabligh referred to kitab Fadāilul 'A'mal which teaches innovations in Islamic propagations. Some of their preaching traditions included outdoor preaching (khurüj dan khillah) and the method to invite people to do good deeds (Jaulah). They have Amir as their leader and use the mosque as their center of da'wa activities. Using Diffusion of Information and Influence Theory, the article discusses the existence of the Jamaah Tabligh community and the public's responses toward the community.
\end{abstract}

Keywords: Tabligh, Jamaah, Faḍailul A'mal, Khurūj, Jaulah 
Keberadaan kelompok Jamaah Tabligh dan Reaksi Masyarakat

(Perspektif Teori Penyebaran Informasi dan Pengaruh)

\section{Pendahuluan}

Jamaah Tabligh ${ }^{1}$ merupakan gerakan keagamaan transnasional yang pada mulanya lahir dan berkembang di India. Gerakan ini didirikan pada tahun 1926 di Mewat India dengan Syaikh Maulana Muhammad Ilyas Kandahlawy bin Maulana Ismail al-Kandahlawy (1885-1944) sebagai tokoh pendirinya. Ia merupakan keturunan dari keluarga alim dan ahli agama di Mewat. ${ }^{2}$ Gerakan ini berkembang pesat tidak hanya di wilayah India dan Bangladesh, namun juga ke berbagai belahan dunia lainnya, termasuk Indonesia. ${ }^{3}$

Di Indonesia gerakan ini konon mulai muncul pada tahun 1952 di Masjid al-Hidayah Medan. Hal itu dibuktikan dengan keberadaan prasasti yang terdapat di masjid tersebut. Gerakan ini semakin nyata menunjukan keberadaannya pada tahun 1974 yang berpusat di Masjid Kebon Jeruk Jakarta. Keberadaan markas ini menunjukkan bahwa Jamaah Tabligh di Indonesia telah mendapatkan tempat dan tanggapan positif, terlebih dengan banyaknya pengikut jamaah ini di Nusantara. Lebih dari itu lembaga kaderisasi dai Jamaah Tabligh juga telah didirikan yang dipusatkan di Pondok Pesantren al-Fatah Magetan Jawa Timur. ${ }^{4}$

Menurut berbagai hasil penelitian, gerakan ini dianggap sebagai gerakan transnasional terpenting dan terbesar saat ini. ${ }^{5}$ Terdapat istilah yang berbeda-beda dalam mengkategorisasikan gerakan ini. Di antaranya, WAMY

${ }^{1}$ Istilah Jamaah Tabligh sendiri bukan berasal dari mereka sendiri, akan tetapi dari orang luar jamaah yang menjuluki mereka karena melaksanakan aktifitas tabligh secara berjamaah. Sedangkan bagi komunitas ini menyebut gerakan mereka sebagai gerakan iman (Tahriki Iman). Lihat Yusran Razak "Jamaah Tabligh Ajaran dan Dakwahnya," Disertasi Doktor Sekolah Pascasarjana UIN Jakarta (2008), 28.

${ }^{2}$ Ia belajar agama di madrasah dekat rumahnya dan dididik oleh kakeknya, Muhammad Yahya. Sejak usia 10 tahun ia sudah hafal Alquran. Ia juga murid dari sejumlah ulama terkemuka Deoband. Sejak kepulangannya dari tanah suci untuk menunaikan ibadah haji yang ke tiga pada tahun 1932, ia bertekad keras untuk melaksanakan tugas suci yaitu berdakwah. Sejak saat itu ia membentuk jamaah-jamaah yang dikirim ke beberapa daerah di sekitar India.

${ }^{3}$ Gerakan ini bahkan disebut-sebut sebagai gerakan keagamaan dan dakwah terbesar di dunia pada abad ini yang memiliki pengaruh luas bahkan di hampir setiap negara yang berpenduduk muslim sunni. Lihat Yoginder Sikand, "Sufisme Pembaharu Jamaah Tabligh", dalam Martin van Bruinessen dan Julia Day Howell, ed. Urban Sufism, (Jakarta: Rajawali Pers, 2008) 221.

${ }^{4}$ Khalid Mas'ud, ed., Travellers in Faith, sebagaimana dikutip oleh Yusran Razak, "Jamaah Tabligh, Ajaran dan Dakwahnya," Disertasi Doktor, Sekolah Pascasarjana UIN Jakarta (2008). 60

${ }^{5}$ Dale F. Eickelman dan James Piscatori, Politik Muslim: Wacana Kekuasaan dan Hegemoni dalam Masyarakat Muslim, terj. Endi Haryono dan Rahmi Yunita (Yogyakarta: Tiara Wacana, 1998). 
menyebut Jamaah Tabligh sebagai sufi pembaharu dengan gerakannya untuk memperbaharui tradisi populer yang berkembang saat itu, yaitu tradisi Hindu dan juga pengaruh penjajahan Inggris. Saat itu, Maulana Ilyas dan pengikutnya mengajak kaum muslim agar mengikuti semua sunah Nabi dengan setia dan meninggalkan apa yang dicela sebagai kebiasaan yang tidak islami. ${ }^{6}$ Muhammad Ilyas percaya bahwa hanya melalui gerakan Islam yang mengakar pada akar rumput, pendidikan dasar keimanan dan ibadah dapat menyelamatkan mereka dari pengaruh Hinduisme. ${ }^{7}$

Pandangan senada juga dikemukan oleh Yoginder Sikand yang menyebut kelompok ini sebagai gerakan tasawuf berbasis syariah, di mana mazhab Deoband sangat peduli menyelaraskan tarekat dengan syariah yaitu perjalanan mistis spiritual dengan jalur lahiriyah hukum. ${ }^{8}$ Sementara itu, Yusran Razak menyebutkan gerakan ini sebagai gerakan tradisionalis transnasional (transnational traditionalist). Mereka berpegang teguh pada syariah dan sunah sebagaimana dicontohkan oleh para pendahulunya yang tidak hanya bersifat lokal, namun bersifat dan berlaku secara global. ${ }^{9}$ Sementara itu Nasrullah menyebut gerakan ini memiliki cara dakwah yang tradisional terlihat dari kecenderungan sikap dan pemikiran untuk selalu mempertahankan tradisi dan warisan masa lalu. ${ }^{10}$

Komunitas ini menekankan kepada setiap pengikutnya untuk meluangkan sebagian waktu untuk menyampaikan dan menyebarkan dakwah dengan akhlak yang baik dan penampilan yang sederhana serta menghindari persoalan khilafiyah dan politik. Berbeda dengan gerakan transnasional lainnya yang melakukan gerakannya secara besar-besaran dan sporadis dengan memanfaatkan beragam jaringan dan media untuk memperjuangkan pemikiran dan ideologinya bahkan pada hal-hal khilafiyah, ${ }^{11}$ Jamaah Tabligh

\footnotetext{
${ }^{6}$ Lembaga Pengkajian dan penelitian WAMY, Gerakan Keagamaan dan Pemikiran: Akar Ideologi dan Penyebarannya (Jakarta: Al-I’tishom, 2006), 76-77

${ }^{7}$ Abdul Aziz, "The Jamaah Tabligh Movement in Indonesia; Peaceful Fundamentalist", Studia Islamika, Vol 11, No. 3. 2004

${ }^{8}$ Yoginder Sikand "Sufisme Pembaharu Jamaah Tabligh," dalam Martin van Bruinessen dan Julia Day Howell, Urban Sufism (Jakarta: Rajawali Press, 2008), hlm. 223.

${ }^{9}$ Razak, "Jamaah Tabligh, Ajaran dan Dakwahnya".

${ }^{10}$ Nasrullah, "Tradisionalisme Dalam Dakwah: Studi Kritis Aktivitas Jamaah Tabligh Kebon Jeruk Jakarta," Tesis Master, Sekolah Pascasarjana Universitas Islam Negeri Jakarta (2005), 20.

${ }^{11}$ Gerakan Keagamaan transnasional, seperti Hizbut Tahrir misalnya mensosialisasikan gagasan dan nilai-nilai dasar perjuangannya dan aktifitas dakwahnya melalui penggunaan media massa, seperti buku-buku koran, majalah, TV, radio, internet, dan lainnya. Demikian
} 
sangat menghindari penggunaan media massa untuk berdakwah baik dalam bentuk media tulis maupun media elektronik. Ceramah di hadapan masyarakat berskala besar secara terbuka juga dihindari oleh komunitas ini.

Jamaah Tabligh juga dikenal memiliki kebiasaan dan tradisi yang unik yang sarat dengan berbagai macam simbol dalam penampilan fisik, seperti memelihara jenggot serta pakaian khas dengan model jalabiya (celana longgar cingkrang dengan baju atasan panjang hingga lutut). Selain itu, ciriciri lain mereka adalah menggunakan parfum beraroma khas, makan bersama dengan tangan dalam satu nampan, kebiasaan menggunakan siwak untuk menjaga kebersihan mulut, dan masih banyak lagi ciri khas lainnya yang sarat dengan makna kebajikan dan mengikuti sunnah. ${ }^{12}$

Komunitas ini menggunakan metode dakwah dengan simpatik dan akhlak yang baik dengan semangat ukhuwah dan tidak sektarian serta menghindari masalah khilafiyah. Oleh karenanya, komunitas ini dengan mudah telah masuk ke berbagai wilayah, negara dan kelompok. Dalam waktu kurang dari dua dekade perkembangan Jamaah Tabligh bahkan dapat ditemukan di banyak negara bahkan benua. ${ }^{13}$

Anggota dari komunitas ini ada di berbagai kelompok, organisasi, aliran, dan paham keagamaan karena misi mereka adalah menghindari masalah-masalah khilafiyah, namun mengutamakan rasa persaudaraan. Sikap demikian dari perspektif akhlak sosial sangat menguntungkan bagi komunitas ini. Tidak heran kalau kelompok Jamaah Tabligh banyak menarik simpati berbagai kalangan masyarakat, khususnya di desa Gerem Kota Cilegon sebagaimana penelitian ini dilakukan.

Beberapa pertanyaan akan menjadi fokus penelitian seperti bagaimana keberadaan kelompok Jamaah Tabligh dan reaksi masyarakat dalam perspektif teori penyebaran informasi dan pengaruh? Apakah bentuk penemuan dari komunitas ini? Bagaimana mereka melakukan proses informasi? Lalu bagaimana dampaknya terhadap kehidupan masyarakat? Akan menjadi fokus penelitian ini. Adapun metode penelitian yang digunakan adalah metode kualitatif melalui pengamatan dan wawancara.

juga dengan gerakan Ahmadiyah, di samping dengan menggunakan media massa yang ada ia juga memiliki jaringan televisi sendiri.

${ }^{12}$ Lihat hasil Penelitian M. Yusuf Asry, "Makna Komunikasi Non-Verbal Dalam Dakwah: Penelitian Simbol Dakwah Jamaah Tabligh,” Jurnal Harmoni, Vol VI, Nomor 23, 2007.

${ }^{13}$ Lihat ulasan Republika dalam dua edisi tentang Jamaah Tabligh Gerakan Dakwah Transnasional, 12 September 2012, http/www.republika.co.id, diakses pada 20-02-2014 


\section{Pembahasan}

\section{A. Teori Penyebaran Informasi dan Pengaruh Jaringan Interpersonal}

Menurut Stephen W. Littlejohn dan Karen A. Foss dalam bukunya Teori-teori Komunikasi (Theories of Human Communication), bahwa dalam komunikasi bahasa erat hubungannya dengan budaya dan masyarakat, di mana keduanya saling mempengaruhi satu sama lain. Suatu gagasan dapat berkembang atau tidak, berpengaruh atau tidak, tergantung pada proses penyebaran kemudian baru berdampak terhadap masyarakat. Setidaknya ada lima tradisi yang membahas tentang budaya dan dalam hubungannya dengan proses komunikasi.

Pertama, tradisi Semiotik, yaitu menghubungkan antara bahasa dengan budaya terlihat dalam teori relatifitas linguistik dan teori tentang kode-kode bahasa. ${ }^{14}$ Kedua, tradisi Sibernetika, yaitu menghubungkan masyarakat dengan penyebaran informasi, dalam hal ini ada dua teori, yaitu dinamika efek sosial dan teori penyebaran informasi dan pengaruh. ${ }^{15}$ Ketiga, tradisi Fenomenologi, yaitu teori tafsir budaya. ${ }^{16}$ Keempat, tradisi Sosiokultural (Ethnography of Communication dan Performance Ethnography). ${ }^{17}$ Kelima adalah tradisi Kritis. ${ }^{18}$

Secara aplikatif teori yang digunakan dalam kajian ini adalah teori penyebaran informasi dan pengaruh dari Everett Rogers. Teori ini menjelaskan bahwa penyebaran informasi memiliki dampak terhadap perubahan sosial. Teori ini didasarkan pada tiga proses perubahan sosial yaitu penemuan, penyebaran informasi dan dampak, dan akibat atau pengaruh. $^{19}$

Perubahan terjadi baik secara internal dari dalam sebuah komunitas atau juga dari luar melalui hubungan dengan agen perubahan dari luar kelompok. Menurut Rogers dibutuhkan waktu yang lama dalam menyebarkan suatu pemikiran. Keberadaan agen perubahan diharapkan dapat mempersingkat hasil dari sebuah inovasi atau pemikiran. Sebuah inovasi akan memiliki akibat baik fungsional maupun disfungsional, akibat langsung maupun tidak langsung, secara nyata maupun tersembunyi.

\footnotetext{
${ }^{14}$ Stephen W. Little Jhon dan Karen A. Foss, Theories of Human Communication (Canada: Thomson Learning Academic Resource Center, 2005). 302

${ }^{15}$ Jhon dan Foss, Theories of Human Communication. 306

${ }^{16}$ Jhon dan Foss, Theories of Human Communication. 310

${ }^{17}$ Jhon dan Foss, Theories of Human Communication. 312

${ }^{18}$ Jhon dan Foss, Theories of Human Communication. 316

${ }^{19}$ Jhon dan Foss, Theories of Human Communication. 308-309
} 
Salah satu contoh penyebaran inovasi digambarkan dengan baik dalam keberhasilan program Keluarga Berencana (KB) di Korea Selatan tahun 1968. Dari hasil penelitiannya, Rogers menemukan bahwa jaringan interpersonal menjadi yang terpenting dalam proses penyebaran dan penggunaan. Ada dua variabel jaringan yang penting dalam hal ini. Pertama, di mana pemimpin klub ibu terhubung dengan orang lain dalam jaringan desa. Kedua, jumlah jaringan antara jaringan $\mathrm{KB}$ dan jaringan desa secara umum. Tingkat penggunaan juga ditentukan oleh cara pandang manfaat dari inovasi tersebut dan kesesuaiannya dengan nilai-nilai dan pengalaman yang ada. Di sinilah pentingnya pengaruh interpersonal dalam proses penyebaran, sebab manusia meningkatkan kesadarannya akan inovasi ketika mereka membicarakannya. dengan menganjurkan penggunaannya atau menolaknya. ${ }^{20}$

Dalam proses penyebaran informasi, mereka membagi opini, membahas pengalaman dan kadang menganjurkan atau menolak. Manusia berbeda dalam memberikan dukungan sosial dalam menggunakan sebuah gagasan, praktik atau obyek-obyek baru. Selalu akan ada individu yang menggunakan inovasi lebih awal dan kemudian memengaruhi orang lain untuk mengikutinya. Sebagian orang akan mengadopsi lebih cepat sebuah inovasi dan sebagian lainnya ada juga yang lambat melakukannya. Intinya, teori ini menghubungkan penyebaran informasi dengan perubahan sosial, yang terdiri atas penemuan, penyebaran dan akibat atau dampak, seperti terlihat dalam skema di bawah ini.

\section{Inovasi / Penemuan}

Teori tersebut di atas akan digunakan dalam artikel ini sebagai alat analisa keberadaan kelompok Jamaah Tabligh yang melakukan inovasi dalam berdakwah, berbeda dari tradisi dakwah di masyarakat pada umumnya. Artikel ini mencoba memahami konteks keberadaan kelompok Jamah Tabligh dan juga reaksi masyarakat baik yang positif maupun negatif serta dampak atau pengaruh kehadiran dan model dakwah komunitas ini bagi masyarakat dalam perspektif teori Everett Rogers ini. Berdasarkan teori ini, salah satu faktor penting dalam proses penyebaran informasi adalah pengaruh

\footnotetext{
${ }^{20}$ Jhon dan Foss, Theories of Human Communication. 308-309
} 
orang. Semakin luas informasi tersebar dan semakin banyak orang membicarakan maka semakin luas dampak yang akan diakibatkan.

\section{B. Jamaah Tabligh dan Penyebaran Informasi Keagamaan}

Jamaah Tabligh merupakan gerakan dakwah yang berpijak pada penyampaian (tabligh) secara berjamaah dengan materi tentang keutamaankeutamaan ajaran Islam kepada setiap orang yang ditemuinya. Dalam hal ini umat Islam menjadi sasaran utama dakwah mereka. Model dakwah semacam ini didasarkan pada alasan bahwa jika umat Islam sudah menjalankan ajaran dan tradisi Islam secara benar dan baik, maka akan menjadikan seluruh dunia baik. Dengan demikian umat di luar Islam juga akan merasakan kebaikannya sehingga umat Islam akan menjadi teladan bagi umat lainnya. Meskipun sasaran utama dakwah ini adalah umat Islam, bukan berarti mengabaikan dakwah terhadap non-muslim karena hal itu juga sangat penting setelah terlebih dahulu membenahi diri sendiri dari dalam. ${ }^{21}$

Dalam komunitas Jamaah Tabligh terdapat beberapa konsep, pokokpokok ajaran, dan istilah-istilah yang sangat identik dengan komunitas ini. Dalam hal ini, konsep-konsep tersebut akan dihubungkan dengan tahapantahapan dalam teori Everett Rogers. Di antara istilah-istilah itu sebagai berikut:

Istilah Jamaah tidak sekedar bermakna perkumpulan, namun istilah tersebut memiliki lima ciri utama, yaitu sekelompok orang yang mempunyai tujuan yang satu, kerja, semangat, hati, dan kasih sayang. ${ }^{22}$ Sedangkan Tabligh merupakan aktifitas mereka dalam menyebarkan ajaran agama. Jadi Jamaah Tabligh bisa bermakna kumpulan orang-orang yang melakukan tabligh atau bertabligh yang dilakukan secara berjamaah.

Kemunculan komunitas ini dan model dakwah mereka merupakan sesuatu yang baru dalam tradisi dakwah pada masyarakat Islam. Mereka juga menggunakan simbol-simbol sebagai ciri atau identitas yang merujuk kepada sunnah sebagai media dakwahnya, di samping perilaku atau da'wah bi al hăal sebagai contoh baik dari mereka. Fadāilul'Amal merupakan pijakan dakwah

\footnotetext{
${ }^{21}$ Lihat adab dan pokok ajaran Jamaah Tabligh dalam beberapa tulisan seperti karya Maulana Muhammad Yusuf al-Kandahlawy, Sifat Sahabat dan Amalan Nurani (Bandung: Pustaka Ramadhan, tt) dan Razak, "Jamaah Tabligh, Ajaran dan Dakwahnya".

${ }^{22}$ Husen Usman Kambayang, Usaha Dakwah dan Tabligh (Bandung: Pustaka Rahadha, 2005), 10
} 
dan rujukan bagi mereka dalam berdakwah sebagai hasil penemuan pendirinya. $^{23}$

Amir adalah sebutan bagi pemimpin mereka sesuai dengan tingkatannya yang disepakati bersama berdasarkan hasil musyawarah. Setiap aktifitas tabligh mereka dilakukan secara berjamaah walaupun dalam jumlah kecil tetap harus ada pemimpinnya. Mereka diharuskan taat pada pemimpin setiap kali melakukan khurüj, jaulah, dan chillah, sebagaimana yang ditetapkan dalam adab dan ajaran dalam komunitas ini. ${ }^{24}$

Jaulah adalah bentuk penyebaran informasi keagamaan dalam bentuk komunikasi interpersonal melalui pendekatan silaturahmi atau berkunjung kepada sasaran dakwah. Prinsip ini nampaknya lahir dari asumsi bahwa dakwah adalah urusan hati, maka yang harus diutamakan adalah menyentuh hati sasaran dakwah dengan mendekatinya. Dakwah bagi mereka tidak dilakukan dari jarak jauh apalagi menggunakan media massa.

Model dakwah seperti ini pada dasarnya lebih mendekatkan komunikator dengan komunikannya dan memungkinkan komunikator lebih mudah memengaruhi secara persuasif. Namun disayangkan sebagai komunikator, seringkali ditemukan orang yang menyampaikan dakwah dari komunitas ini bukan orang yang memiliki otoritas keilmuan agama. Bahkan tidak jarang yang menjadi komunikator adalah orang yang tidak jelas rekam jejaknya atau diragukan kemampuan dan kredibilitasnya sehingga sulit menghasilkan pengaruh pribadi dalam memengaruhi masyarakat atau orang lainnya. ${ }^{25}$

Khurüj merupakan aktifitas rutin yang harus dilakukan oleh aktivis dakwah dalam komunitas jamaah ini. Ia harus rajin keluar rumah untuk mengajak orang lain pada kebajikan dan mengingatkan orang lain dari azab

\footnotetext{
${ }^{23} \mathrm{Kitab}$ ini merupakan rujukan utama mereka dalam berdakwah yang ditulis oleh Maulana Muhammad Zakaria al-Kandahlawi. Kitab asilnya ditulis dalam bahasa Urdu dan telah diterjemahkan ke dalam berbagai bahasa termasuk dalam bahasa Indonesia.

${ }^{24}$ Lihat adab dan pokok ajaran Jamaah Tabligh dalam beberapa tulisan seperti karya alKandahlawy, Sifat Sahabat dan Amalan Nurani, dan Razak, "Jamaah Tabligh, Ajaran dan Dakwahnya".

${ }^{25}$ Dalam ilmu komunikasi, seorang komunikator harus memiliki etos komunikator yang meliputi kompetensi, kredibilitas atau karakter yang baik, dan itikad dan tujuan yang baik. Sebab etos komunikator sangat menentukan keberhasilan dan efektifitas dari komunikasi yang disampaikan. Terlebih bagi seorang da'i/mubaligh, kompetensi keagamaan merupakan suatu keniscayaan yang didukung oleh kemampuan cara menyampaikan dan akhlak yang mulia. Lebih jelas tentang pentingnya etos bagi komunikator (Lihat Jalaludin Rahmat, Psikologi Komunikasi (Bandung: Rosdakarya, 2003) dan Onong Uchyana, Ilmu, Teori, dan Filsafat Komunikasi (Bandung: Citra Aditya Bakti, 2003).
} 
Tuhan. Aktivis dakwah, dikenal dengan istilah karkun, harus meluangkan waktu secara maksimal dan sebaik-baiknya untuk kepentingan dakwah. Khurūj di sini bukan sekedar keluar, akan tetapi khurūj fi sabīlillāh. Oleh karena itu komunitas ini seringkali terlihat berkeliling dari rumah ke rumah, dari satu kampung ke kampung yang lain, dari satu daerah ke daerah lainnya bahkan dari satu negara ke negara lainnya.

Khurūj merupakan bentuk dakwah dengan pengorbanan waktu karena ia memakan waktu banyak sampai berhari-hari bahkan berbulan-bulan. Bagi aktivis Jamaah Tabligh, waktu yang berharga adalah waktu yang digunakan untuk mengajak diri, keluarga, dan orang lain di jalan Allah. Waktu yang digunakan untuk khurüj seharusnya lebih banyak daripada waktu untuk urusan dunia maupun istirahat dan bersenang-senang. Untuk itu mereka seringkali khurüj, keluar dalam waktu yang lama meninggalkan keluarga, anak, dan isteri. Ketika mereka sedang khurüj bahkan tidak boleh diganggu oleh urusan keluarga dan urusan keduniaan lainnya. ${ }^{26}$

Chillah merupakan rutinitas aktivis jamaah yaitu keluar rumah atau kampung untuk bertabligh dengan waktu-waktu yang ditentukan, dalam hal ini minimal tiga hari dalam satu bulan, empat puluh hari dalam satu tahun dan empat bulan dalam seumur hidup. Chillah juga dilakukan secara berjamaah di mana aktivis jamaah berasal dari berbagai wilayah yang kemudian menyatu dalam aktifitas tabligh di masjid.

Masjid digunakan sebagai basis dakwah komunitas ini. Melalui masjid, tabligh mereka mudah terlihat dan dapat ditekun, didengar, dan diikuti oleh masyarakat sehingga diharapkan dapat berdampak langsung pada masyarakat. Masjid mereka gunakan untuk melakukan berbagai aktifitas dari bayan, tidur, sampai memenuhi kebutuhan makan minum. Oleh karenanya, dalam aktifitas ini mereka kerap membawa alat-alat rumah tangga untuk kegiatan makan, minum dan masak. Permasalahan yang muncul adalah mereka sulit mendapatkan masjid yang dapat digunakan sebagai pusat dakwah mereka, karena tidak jarang mereka mendapat penolakan bahkan pengusiran dari masyarakat disebabkan aktifitas yang dilakukan ini.

\footnotetext{
${ }^{26}$ Bahkan untuk kepentingan keluarga yang darurat sekalipun seperti ketika isterinya mau melahirkan, aktifis Jamaah Tabligh yang sedang khurüj tidak boleh diganggu. Untuk urusan keluarga seperti mengirim uang at au pesan dilakukan melalui ut usan, teman atau orang yang dipercayainya (Hasil wawancara dengan Hadikoh isteri dari salah satu aktifis Jamaah Tabligh, Cilegon, 10 Mei 2013).
} 
Keberadaan kelompok Jamaah Tabligh dan Reaksi Masyarakat

(Perspektif Teori Penyebaran Informasi dan Pengaruh)

\section{Khurūj, Jaulah, Chillah, dan Tanggapan Masyarakat}

Keberadaan dan kehadiran komunitas Jamaah Tabligh di tengahtengah masyarakat memunculkan berbagai reaksi yang beragam baik yang positif maupun negatif terhadap aktifitas dakwah mereka. Selain itu, masjid yang mereka jadikan markas serta tempat pertemuan rutin bulanan ini seringkali diambil alih oleh komunitas keagamaan lain di luar Jamaah Tabligh sehingga mereka harus berpindah dari satu masjid ke masjid lainnya. Dengan demikian, pertemuan bulanan yang mereka lakukan selalu berpindahpindah dan saat ini mereka menggunakan rumah jemaah dengan berpindah dari satu rumah ke rumah lainnya. Berdasarkan keadaan inilah, penelitian ini dilakukan. Penelitian ini menyoroti lebih dalam kasus yang terjadi di beberapa masjid di lingkungan perkampungan di kota Cilegon, khususnya di Desa Gerem.

Jamaah Tabligh berkembang di wilayah Cilegon sejak awal tahun 90an yang dibawa oleh kaum pendatang. Meskipun sebenarnya komunitas ini telah jauh sebelumnya masuk dan melakukan aktifitas tabligh di beberapa masjid di wilayah tersebut oleh aktivis dakwah dari wilayah lain. ${ }^{27}$ Saat itu belum ada jemaah yang terorganisir di kota tersebut, walaupun secara perorangan kemungkinan sudah ada dan bisa jadi menginduk dengan wilayah lain yang terdekat.

Berdasarkan penuturan bapak H. Kusnanto (Mas Kus) seorang Anggota Jamaah Tabligh di Cilegon, keberadaan Jumindar sebagai penanggung jawab wilayah Jamaah Tabligh untuk wilayah Cilegon pertama kali ada sekitar tahun 1995. Sementara itu keanggotaan jamaah atau karkun di kota Cilegon tidak pasti karena tidak ada catatan administratif keanggotaan namun diperkirakan saat ini kurang lebih berjumlah 200-300 orang. Meskipun demikian yang aktif mengikuti pertemuan rutin bulanan di Cilegon kurang lebih 100 orang. Demikian juga yang mengikuti pertemuan tiga bulanan di Kebon Jeruk, Jakarta. Komunitas ini bersifat terbuka, artinya siapa saja dan kapan saja boleh masuk atau keluar dari jamaah ini. Sehingga

\footnotetext{
${ }^{27}$ Menurut KH. M. Hilman Isma'il, tokoh masyarakat di Desa Gerem, kelompok jaulah (untuk menyebut Jamaah Tabligh) mulai terlihat di wilayah ini sejak tahun 70 hingga 80-an dengan cara berkeliling dari satu masjid ke masjid yang lain untuk beberapa hari dengan membawa perabot rumah tangga. Namun setelah itu pergi lagi karena umumnya mereka adalah orang luar dan setahun atau beberapa tahun kemudian hadir lagi (Wawancara dengan KH. M. Hilman Isma'il, Cilegon, 10 Mei 2013).
} 
jamaahnya beragam baik dari aspek usia, profesi maupun latar belakang aliran dan mazhab. ${ }^{28}$

Menurut informasi dari beberapa aktivis Jamaah Tabligh, komunitas ini terdiri dari berbagai macam profesi. Ada karyawan dari berbagai tingkatan, wiraswasta, pensiunan, pelajar, PNS, dan lain-lain. Diperkirakan mayoritas di antara mereka adalah karyawan. ${ }^{29}$ Sesungguhnya dengan profesi demikian mereka menghadapi peraturan perusahaan yang ketat. Namun demikian mereka menyiasatinya untuk dapat bertabligh di luar jam kerja dengan melakukan khurüj. Adapun untuk chillah bulanan selama 3 hari biasanya mereka mengambil waktu hari libur atau mengambil cuti dan diadakan di lingkungan masjid yang tidak jauh dari tempat kerja. Demikian juga untuk chillah dalam waktu lama 40 hari. Untuk chillah empat bulan sebagian belum dapat melakukannya karena harus melihat keadaan waktu yang belum memungkinkan atau menunggu waktu pensiun.

Pada umumnya komunitas ini tidak menonjolkan identitas mereka secara lisan. Mereka tidak menyebutkan atau memperkenalkan diri sebagai anggota Jamaah Tabligh. Akan tetapi, identitas tersebut terihat dan mudah ditebak melalui simbol-simbol yang mereka gunakan. Oleh karenanya, masyarakat mengenal mereka melalui penampilan luar dan menyebut mereka dengan sebutan kelompok jaulah, jenggot atau kelompok cingkrang dalam bahasa lokal Cilegon.

Aktifitas dakwah komunitas Jamaah Tabligh tidak selamanya diterima oleh masyarakat bahkan terkadang ditolak. Sebutan di atas sesungguhnya merupakan sebutan yang penuh kecurigaan bahkan mengkritik kebiasaan dan aktifitas komunitas tersebut. Kecurigaan tersebut muncul oleh karena sebagian masyarakat tersebut sesungguhnya belum mengerti maksud, tujuan, dan ajaran komunitas ini. Sikap ini tidak jarang melahirkan sikap penuh kecurigaan yang tercermin dalam bentuk penolakan untuk memberikan izin terhadap penggunaan masjid-masjid yang akan mereka gunakan sebagai tempat pengajian.

\footnotetext{
${ }^{28}$ Wawancara dengan Bapak H. Kusnanto, Cilegon, 10 Mei 2013.

${ }^{29}$ Untuk jumlah anggota komunitas atau jamaah ini tidak diperoleh angka yang pasti karena tidak ada catatan administratif, maupun keanggotaan secara resmi. Karena hal ini tidak lazim bagi komunitas ini, ikatan mereka adalah ikatan emosi dalam panggilan dakwah. Namun dari hasil wawancara penulis dengan beberapa aktifis dakwah yang sedang khurüj di mushalla Al-Hikmah-Gerem (1-3 Mei 2013) rata-rata pekerjaan mereka adalah karyawan pabrik, bahkan juga ada di antaranya yang berasal dan bekerja di luar wilayah Cilegon.
} 
Tanggapan masyarakat terhadap komunitas Jamaah Tabligh sangat beragam. Sebagian ada yang menerima lalu menjadi pengikut setia jamaah ini. Sebagai contoh, di desa ini terdapat beberapa aktivis jamaah tabligh yang sangat aktif bahkan sering melakukan khurüj ke berbagai daerah sampai ke pelosok Nusantara. Salah satunya adalah H. Jahuri yang merupakan penduduk asli Gerem. Laki-laki paruh baya ini sudah keluar dari pekerjaannya dan saat ini menghabiskan waktunya aktif melakukan tabligh, baik di lingkungan sekitarnya maupun ke luar daerah. Aktivis lainnya adalah H. Kusnanto yang merupakan pendatang namun menikah dengan perempuan Gerem. Walaupun ia masih menjadi karyawan aktif di salah satu perusahaan di kawasan Ciwandan Cilegon, ia tetap aktif melakukan tabligh, chillah, dan juga khurūj di sela-sela kesibukannya sebagai karyawan. Melalui mereka inilah komunitas Jamaah Tabligh saat ini kerap ditemukan melakukan aktifitas di beberapa masjid di lingkungan Desa Gerem yang terkadang digunakan juga untuk tempat tabligh tahunan.

Ada juga kelompok yang sekedar simpatik menjadi partisipan, di mana sekali-kali mereka hadir dan pernah ikut melakukan chillah, misalnya $\mathrm{H}$. Hajib dan Sapardin. Walaupun tidak aktif, mereka pernah mengikuti dan ikut kegiatan jamaah ini. Selain itu, ada juga kelompok yang menolak, seperti misalnya $\mathrm{H}$. Karim yang menolak tegas kehadiran komunitas ini di Masjid alMunawwaroh Gerem. Demikian juga dengan H. Abdullah, Ustaz Zubaedi, dan Ustaz Syihabuddin yang tidak memberikan izin penggunaan masjid untuk aktifitas jamaah ini.

Komunitas Jamaah Tabligh di wilayah ini belum memiliki markas khusus yang permanen sebagai tempat bayan dan juga pembinaan. Hal itu terlihat dari perjalanan aktivis Jamaah Tabligh di kota Cilegon yang markasnya berpindah-pindah dari satu masjid ke masjid lain. Keadaan ini menarik untuk dikaji dalam hubungannya dengan reaksi masyarakat. Apakah pindahnya mereka dari satu masjid ke masjid lain karena semata-mata untuk menyebarkan dakwah secara luas dan merata atau karena sulitnya menemukan masjid yang dapat menjadi basis untuk aktifitas tabligh mereka dikarenakan terdapat penolakan oleh masyarakat sekitar.

Menurut Pak Kusnanto, seorang aktivis senior, semula mereka bermarkas di masjid komplek perumahan Pondok Cilegon Indah (PCI). Mereka mengadakan pertemuan rutin dan bayan bulanan yang dihadiri oleh para jamaah dan isteri di masjid tersebut. Namun pengurus DKM masjid tersebut tidak seluruhnya setuju terhadap komunitas ini, sehingga kegiatan 
jamaah ini tidak dilakukan di masjid tersebut. Jamaah ini kemudian mengadakan aktifitasnya di masjid perumahan Arga Baja Cilegon dan berlangsung kurang lebih satu tahun. Lama kelamaan masjid ini juga dijadikan basis aktifitas dari jamaah (kelompok keagamaan) lainnya. Akhirnya aktifitas Jamaah Tabligh juga berpindah dengan melaksanakan pertemuan dan bayan dari rumah ke rumah. ${ }^{30}$

Keadaan di atas menunjukan bahwa tidak semua masyarakat menerima kehadiran dan model dakwah komunitas Jamaah Tabligh. Bahkan ada beberapa di antaranya menolak bahkan mengusir komunitas Jamaah Tabligh baik secara langsung maupun tidak langsung. Permasalahan yang seperti ini tidak hanya terjadi di wilayah ini. Kondisi ini membuat mereka seolah "berebut masjid" dengan organisasi Islam lainnya. Tidak jarang mereka kerap kali terusir atau mengalah untuk kemudian berpindah ke tempat lain. ${ }^{31}$

Namun peristiwa tersebut tidak menjadikan komunitas Jamaah Tabligh marah. Mereka menerimanya dengan ikhlas sebagaimana terdapat dalam ajaran pokok mereka yaitu memuliakan orang Islam serta mengutamakan persaudaraan dan menghindari permusuhan dan pertikaian. ${ }^{32}$

Demikian juga ketika mereka melaksanakan khurüj dan chillah. Tidak semua masyarakat menerima mereka. Bahkan mereka juga pernah ditolak oleh beberapa masjid yang akan mereka gunakan sebagai basis dakwah ketika mereka khurüj dan chillah. ${ }^{33}$ Tidak hanya itu, mereka juga pernah seolah-olah diuji oleh salah seorang pengurus DKM dalam hal membaca Alquran. ${ }^{34}$

${ }^{30}$ Wawancara dengan Bapak Kusnanto, Cilegon, 10 Mei 2013.

${ }^{31}$ Kondisi yang tidak jauh berbeda juga dihadapi oleh komunitas Jamaah Tabligh di Papua Barat. Oleh karena mereka tidak memiliki markas sebagai pusat aktifitasnya, di mana mereka kemudian menggunakan Masjid Agung Jayakarta. Namun tidak semua masyarakat simpatik terhadap keberadaan komunitas ini dan tinggal di masjid agung ini. Lebih jelas tentang keberadaan dan kiprah jamaah tabligh di Papua Barat. Lihat Farish A. Noor, The Arrival and Spread of the Tabligh Jam'at in West Papua Indonesia. RSIS Working paper, No. 191, 10 Pebruari, 2010. http/www.rsis.edu.sg/publications/working paper/wpigi.pdf., diakses 20-02-2014.

${ }^{32}$ Mereka memiliki prinsip-prinsip yang menjadi pokok ajarannya, yaitu kalimat Thayyibah (Là Ilāha illa Allāh Muhammad Rasulullāh), mendirikan shalat dengan khusyu', ilmu dan zikir, memuliakan orang Islam, meluruskan niat, dan dakwah \& tabligh.

${ }^{33}$ Dalam hal ini di antaranya mereka pernah ditolak oleh salah satu pengurus DKM Masjid al-Munawwaroh Gerem dengan alasan mengganggu aktifitas masjid yang umumnya digunakan oleh para santri. Mereka bahkan dianggap akan mengotori masjid karena mereka membawa perlengkapan masak dan melakukan semua aktifitasnya di masjid selama beberapa hari.

${ }^{34}$ Berdasarkan cerita Sapardin tentang pengalamannya mengikuti kegiatan tabligh jamaah ini di salah satu wilayah perkampungan di Kota Cilegon dan Serang di mana di 
Secara lahiriyah masyarakat seringkali menyamakan kelompok ini dengan komunitas Salafi, padahal keduanya memiliki ajaran dan cara pandang yang berbeda. Bahkan kelompok Salafi kerap kali mengkritik komunitas Jamaah Tabligh yang dianggapnya sebagai ahlul bidah. ${ }^{35}$ Dalam pandangan Komunitas Jamaah Tabligh, kaum salafi seringkali menyalahkan orang lain dengan mengarahkan telunjuknya kepada orang lain atas berbagai kesesatan dan kemaksiatan yang terjadi. Bagi Jamaah Tabligh telunjuk itu mestinya diarahkan ke dalam (diri kita), karena menurut Jamaah Tabligh terjadinya kesesatan dan kemaksiatan di tengah masyarakat merupakan kesalahan kita yang kurang maksimal dalam melaksanakan dakwah Islam.

Masyarakat bukan hanya mengkritik inovasi model dakwah Jamaah Tabligh, namun juga pada sumber-sumber yang menjadi rujukan utama mereka seperti kitab Fadailul A'mal dan kitab Hayāt al-Sahạ̄bah. Salah satu kitab yang utama adalah kitab Fa⿳亠丷ailul A'mal yang merupakan hasil penemuan dari tokoh pendirinya. Kitab ini ditulis oleh Maulana Zakariya, salah seorang ulama terkemuka atas permintaan Maulana Ilyas, tokoh pendiri gerakan ini. Kitab ini menjadi pegangan utama sehingga setiap pengikut Jamaah Tabligh umumnya memiliki kitab ini dan menjadikannya sebagai rujukan utama materi dalam bayan dan tabligh mereka.

Kitab ini berisi amalan-amalan yang memiliki keutamaan seperti keutamaan Alquran, keutamaan, salat, keutamaan zikir, keutamaan tabligh, keutamaan Ramadhan, hikayat sahabat, kemerosotan umat, dan lain-lain. ${ }^{36}$ Sementara itu bagi kalangan luar komunitas Jamaah Tabligh, kitab ini dianggap penuh dengan hadis-hadis da'if bahkan maudu', sehingga tidak layak untuk dijadikan pegangan dalam beribadah. Kritik demikian banyak muncul terutama dari kalangan Salafi yang memang selektif dalam menerima dan mengamalkan hadis terlebih dalam kaitannya dengan amal ibadah. ${ }^{37}$

wilayah tersebut masih terdapat banyak pesantren tradisional. Ia bersyukur pernah belajar Alquran dan qira'at dan memiliki basis pendidikan agama di Madrasah Tsanawiyah dan Aliyah. Hasil wawancara dengan Sapardin, Cilegon, 2 Mei 2013.

${ }^{35}$ Lihat Robi' bin Hadi al-Madkholi, Fatwa Ulama Seputar Jamaah Tabligh, terj. Abu Bakar dan Himatur Rahmah (Yogyakarta: Al-Khaura, 2002) dan Abdul Khalik Pirzada, Maulana Muhammad Ilyas di antara Pengikut dan Penentangnya, terj. Masrokhan Ahmad (Yogyakarta: As-Shaf, 2003).

${ }^{36}$ Maulana Muhammad Zakariya al-Kandahlawai, Himpunan Fadhilah 'Amal, terj. A. Abdurrahman Ahmad (Bandung: Ramdhani, tt).

${ }^{37}$ Lihat al-Madkholi, Fatwa Ulama Seputar Jamaah Tabligh dan Abdul Khalik Pirzada, Maulana Muhammad Ilyas di antara Pengikut dan Penentangnya, terj. Masrokhan Ahmad (Yogyakarta: As-Shaf, 2003). 


\section{Efektifitas Model Penyebaran: Eksistensi dan Entitas Jamaah Tabligh}

Melihat perkembangan kelompok Jamaah Tabligh yang fenomenal di berbagai wilayah dan negara sebagaimana digambarkan dalam hasil beberapa penelitian di atas, menunjukkan bahwa keberadaan kelompok ini dan model dakwahnya dapat diterima oleh masyarakat.

Namun demikian harus diakui bahwa penampilan yang sederhan dan akhlak yang mulia dan sikap menghormati orang lain terutama sesama Muslim serta upaya untuk selalu dekat dengan masyarakat dengan cara berkunjung dan mengajak orang lain dalam kebaikan merupakan kelebihan mereka. Sementara itu ada pihak-pihak lain, baik secara perorangan maupun kelembagaan, yang melaksanakan dakwah hanya menunggu panggilan masyarakat. Bahkan tidak jarang terdapat oknum dai yang memiliki nama besar karena dipopulerkan media. Beberapa di antaranya sudah jauh dari nilai-nilai akhlak yang harusnya melekat pada seorang dai baik dari perilaku dan kehidupan sehari-hari yang mewah maupun keberaniannya memasang tarif dan imbalan yang fantastis. ${ }^{38}$

Namun di sisi lain, cara dakwah mereka yang mengacu pada kitab Fadailul A'mal menjadikan materi dakwah mereka sempit dan kaku serta tidak kekinian dan sesuai dengan perkembangan dan kebutuhan umat masa kini. Selain itu, jemaah terputus dengan sumber-sumber ortodoksi Islam dan khazanah kekayaaan Islam yang luas dan lebih mumpuni. Tidak jarang muncul kesan mereka hanya merujuk kepada satu kitab saja. Sementara itu sumber pokok lain seperti Alquran, Hadits, Tafsir, dan hasil ijtihad ulamaulama yang muktabarah tidak mereka geluti.

Khurüj, jaulah, dan chillah merupakan cara mereka berdakwah dengan mendekatkan diri kepada sasaran dakwah. Dakwah atau penyebaran informasi dalam perspektif teori penyebaran informasi menurut Rogers adalah didahului dengan penemuan, inovasi baru penyebaran, dan dampak. ${ }^{39}$ Salah satu penyebaran informasi adalah melalui komunikasi interpersonal, karena yang sebenarnya menyebarkan informasi media ke masyarakat juga sesungguhnya individu melalui komunikasi antar-orang yang kemudian memengaruhi orang lain.

Dalam hal ini pengaruh individu (personal influence) merupakan hal yang paling utama. Teori ini sangat sesuai digunakan dalam memotret

\footnotetext{
${ }^{38}$ Lebih luas ulasan tentang hal ini lihat Republika, Jumat tanggal 13 dan 21 Februari, 2014.

${ }^{39}$ Jhon dan Foss, Theories of Human Communication, 308-309.
} 
keberadaan Jamaah Tabligh, di mana mereka mengandalkan dakwah atau penyebaran informasi melalui komunikasi interpersonal. Mereka tidak menggunakan penggunaaan media massa dalam dakwahnya dan tidak mengandalkan jumlah pendengar yang banyak.

Bila diamati dan dikaji model dakwah atau proses penyebaran informasi dalam komunitas Jamaah Tabligh di atas, sebenarnya juga lahir dari pemahaman mereka terhadap sunnah Nabi dan tradisi kaum salaf dalam berdakwah. Tradisi khurüj, misalnya, didasarkan pada pemahaman mereka terhadap Alquran dan hadis, seperti yang terdapat pada ayat berikut, yang artinya:

"Kamu adalah umat yang terbaik yang dilahirkan atau dikeluarkan untuk manusia menyuruh kepada kebaikan dan mencegah pada kemunkaran...” (Q.S. Al-Imran 3: 110).

Dalam perspektif tafsir, ayat ini sesungguhnya menjelaskan keutamaan umat Islam yang diberikan kewajiban untuk melakukan dakwah karena umat Islam merupakan umat terbaik. Kedudukan umat terbaik di antaranya didasarkan kepada tiga hal, yaitu menyeru kepada kebaikan dan mencegah dari kemungkaran dan beriman kepada Allah. Tanpa ketiga hal tersebut, kedudukan sebagai sebaik-baiknya umat tidak dapat dipertahankan. ${ }^{40}$ Berdasarkan pemahaman ayat ini, keutamaan bagi umat Islam dalam pandangan komunitas ini adalah giat berkeliling bertabligh mengingatkan manusia mengajak kepada kebaikan, dan mencegah dari kemunkaran dan selalu menyerukan keimanan.

"Barang siapa berhijrah di jalan Allah, niscaya mereka mendapati di muka bumi ini tempat hijrah yang luas dan rizki yang banyak. Barang siapa keluar dari rumahnya dengan maksud berhijrah kepada Allah dan Rasulnya kemudian kematian menimpanya maka sungguh pahala telah tetap di sisi Allah" (Q.S. An-Nisa: 100).

Ayat ini memberikan harapan kepada orang yang berniat keluar (hijrah) di jalan Allah yaitu dengan cara mengikuti perintah Allah dan RasulNya. Walaupun belum sampai pada tujuan yang dituju, niscaya ia akan beruntung. Oleh karena berhijrah demi mendapatkan keridhaan Allah dan Rasul-Nya. ${ }^{41}$

\footnotetext{
${ }^{40}$ M. Quraish Shihab, Tafsir Al-Misbah, Jilid 2 (Jakarta: Lentera Hati, 2002).

${ }^{41}$ Shihab, Tafsir Al-Misbah.
} 
Berdasarkan pemahaman terhadap ayat di atas, komunitas Jamaah Tabligh memiliki tradisi dakwah yang khas. Bukan hanya mewajibkan jamaahnya keluar untuk berdakwah, namun juga menentukan aktifitas dakwah mereka dengan jumlah-jumlah hari tertentu seperti khurüj 3 (tiga hari) dalam sebulan, 40 hari dalam setahun, dan 4 (empat) bulan seumur hidup). Ketentuan ini termasuk unik karena hanya ditemukan pada komunitas ini.

Jamaah Tabligh di wilayah ini telah menunjukan keberadaannya. Keberadaan markas dan jumindar untuk wilayah Cilegon serta jumlah jamaah yang sudah mencapai ratusan orang menunjukan bahwa komunitas ini ada di wilayah ini. Ia memiliki dampak pada perubahan sosial masyarakat namun masih dalam lingkungan yang terbatas. Masuknya beberapa pekerja industri dalam komunitas ini, setidaknya memberikan dampak terhadap tumbuhnya nilai-nilai spiritual di lingkungan industri yang bisa menangkal pengaruh negatif dari nilai-nilai modernisme, materialisme, dan hedonisme yang identik dengan kehidupan masyarakat industri. ${ }^{42}$

Nampaknya aktivis dakwah komunitas ini di Cilegon belum mendapatkan dukungan dari tokoh yang memiliki otoritas keagamaan, kharisma atau kepemimpinan yang diakui. Dakwah mereka dikembangkan oleh aktivis-aktivis yang masih muda yang justru umumnya bukan berpendidikan agama. Semangat mereka dapat dihargai secara baik. Namun demikian, pengembangan kualitas dan kemampuan keilmuan keagamaan aktivis merupakan hal yang penting karena akan berdampak pada keberlangsungan keberadaan Jamaah Tabligh dan aktifitas dakwah yang dilakukannya khususnya di wilayah ini.

Berdasarkan keterangan di atas, terlihat adanya kesenjangan antara Sunnah Nabi dan tradisi kaum Salaf (sahabat) dengan kenyataan yang dilakukan oleh komunitas Jamaah Tabligh di wilayah Cilegon. Kesenjangan yang dimaksud adalah belum adanya pemimpin opini yang menjadi unsur penting dalam teori ini, sebab pengaruh perorangan merupakan hal penting dalam proses penyebaran informasi yang belum nampak dalam komunitas jamaah di wilayah ini.

Hal tersebut telah dilakukan oleh Rasulullah ketika mengutus sahabat, yaitu orang yang dianggap memiliki kemampuan untuk berdakwah dan bisa 135.

${ }^{42}$ Nurcholis Madjid, Islam Kemoderenan dan Keindonesiaan (Bandung: Mizan, 1987), 
mengemban apa yang ditugaskan Rasulullah dalam berdakwah ke berbagai wilayah. ${ }^{43}$ Rasulullah mempersiapkan betul kader-kader dakwah dan mengetahui kualifikasi masing-masing individu para sahabat. Tidak hanya sekedar individu yang memiliki semangat dalam berdakwah, namun juga perlu dipersiapkan individu yang memiliki kemampuan dalam ilmu-ilmu keislaman sehingga dapat menyampaikan materi dakwah dengan baik.

Demikian juga bagi seorang dai sebagai pewaris para Nabi, setidaknya memiliki tiga persyaratan utama. Pertama, tafaqquh $\overline{f i}$ al-din, pengetahuan mendalam tentang Islam supaya seorang dai dapat menjelaskan risalah yang sempurna dan tidak menyimpang dari ajaran Islam yang benar. Kedua, Tazkiyatun-nafs, memiliki kekuatan jiwa dalam memiliki menegakan kebenaran dan kebaikan dengan akhlak yang mulia. Ketiga, tafaqquh $\overline{f i}$ alnas, mengetahui dan mengenal dengan baik karakter masyarakat atau mad'u yang menjadi sasaran dakwahnya. ${ }^{44}$ Dalam ilmu komunikasi seorang komunikator harus memiliki etos komunikator. Di mana ia bukan hanya harus memiliki kemampuan tentang apa yang akan disampaikan, namun juga harus memiliki kelayakan dan karakter moral yang baik serta tujuan komunikasi yang baik.

\section{Kesimpulan}

Berdasarkan uraian di atas, penulis mengambil kesimpulan bahwa, kehadiran Jamaah Tabligh dapat tanggapan positif. Mereka juga merupakan bagian dari kekuatan Islam yang bisa bekerjasama dengan kekuataan Islam lainnya. Melalui semangat dakwah yang tinggi menjadikan Islam semakin tersebar luas bahkan sampai pelosok pedalaman. Semangat dakwah mereka merupakan hal yang terpuji dengan segala kelebihan dan kekurangan metode yang mereka lakukan.

Namun demikian, penerimaan ini tidak berarti mengabaikan prasyarat yang harus dimiliki oleh juru dakwah, baik dari aspek kriteria dai di mana minimal memiliki kriteria-kriteria, seperti aspek keilmuan-keagamaan, aspek pemahaman terhadap manusia yang dihadapi dan aspek kematangan jiwa dan kepribadian yang baik serta akhlak yang mulia. Aspek materi dakwah juga

${ }^{43}$ Lihat Thomas W. Arnold, Sejarah Dakwah Islam, Terj. A. Nawawi Rambe (Jakarta: Widjaya, 1980) dan Ali Musthfa Ya'kub, Sejarah dan Methode Dakwah Nabi (Jakarta: Pustaka Firdaus, 1997).

${ }^{44}$ Lihat Muhammad Al-Ghazali, Humumu Da'iyah, Terj. Muhamad Jamaluddin (Bandung; Mizan, 1991). 30-35 
harus dapat diterima secara luas dan bisa memenuhi harapan masyarakat. Kenyataannya, materi dakwah yang diajarkan oleh komunitas ini hanya pada seputar kehidupan sehari-hari dan pada masalah-masalah yang ringan. Persoalan umat sendiri sesungguhnya sangat rumit dan dalam menghadapi tantangan global butuh pemahaman serta pengkajian secara serius dan holistik. Oleh karenanya, materi dakwah seharusnya bukan hanya bersifat mengingatkan, tetapi juga memberikan solusi dan memenuhi kebutuhan masyarakat sehingga dakwah tersebut dapat berdampak pada perubahan sosial masyarakat, sebagaimana yang telah dilakukan oleh para pendahulunya.

Kewajiban untuk berdakwah bukan berarti harus meninggalkan kewajiban lainnya. Mendidik dan memenuhi kebutuhan keluarga juga merupakan kewajiban yang tidak boleh ditinggalkan. Kelompok Jamaah Tabligh memiliki doktrin keluar untuk berdakwah (khurüj dan chillah) dalam waktu yang lama sehingga meninggalkan keluarga dan tidak boleh diganggu oleh urusan keluarga selama menjalankan tugas dakwah. Doktrin ini telah dipahami secara kaku oleh jamaah Bagi mereka ini merupakan prinsip di mana urusan agama Allah di atas segalanya. Sementara bagi sebagian orang yang belum terbiasa mungkin berpandangan negatif terhadap doktrin di atas. Maka hal demikian menjadi masalah dan kendala bagi mereka untuk bergabung menjadi jamaah.

\section{Daftar Pustaka}

Ghazali, Muhammad. Humumu Da'iyah. Terj. Muhamad Jamaludin. Bandung: Mizan, 1991.

Arnold, Thomas W. Sejarah Dakwah Islam. Terj. A. Nawawi Rambe. Jakarta: Widjaya, 1980.

Asry, M. Yusuf. "Makna Komunikasi Non Verbal Dalam Dakwah: Penelitian Simbol Dakwah Jamaah Tabligh.” Jurnal Harmoni, Vol VI, Nomor 23, 2007.

Aziz, Abdul. "The Jamaah Tabligh Movement in Indonesia: Peaceful Fundamentalist." Studia Islamika, Vol 11 No. 3. 2004.

Eickelman, Dale F. dan James Piscatori. Politik Muslim: Wacana Kekuasaan dan Hegemoni dalam Masyarakat Islam. Terj. Endi Haryono dan Rahmi Yunita. Yogyakarta: Tiara Wacana, 1998.

Kambayang, Husen Usman. Usaha Dakwah dan Tabligh. Bandung: Pustaka Rahadha, 2005. 
Al-Kandahlawy, Maulana Muhammad Zakariya. Himpunan Fadhilah 'Amal. Terj. A. Abdurrahman Ahmad. Bandung: Pustaka Ramdhanim, tt.

Al-Kandahlawy, Maulana Muhammad Yusuf. Sifat Sahabat dan Amalan Nurani. Bandung: Pustaka Ramadhani, tt.

Al-Madkholi, Robi' bin Hadi. Fatwa Ulama Seputar Jamaah Tabligh. Terj.

Abu Bakar dan Himatur Rahmah. Yogyakarta: Al-Khaura, 2002.

Lembaga Pengkajian dan Penelitian WAMY. Gerakan Keagamaan dan

Pemikiran: Akar Ideologi dan Penyebarannya. Jakarta: Al-I'tishom, 2006.

Littlejohn, Stephen W. dan Karen A. Foss. Theories of Human

Communication. Canada: Thomson Learning Academic Resource Center, 2005.

Madjid, Nurcholish. Islam Kemoderenan dan Keindonesiaan. Bandung: Mizan, 1987.

Nasrullah. "Tradisionalisme Dalam Dakwah: Studi Kritis Aktivitas Jamaah Tabligh Kebon Jeruk Jakarta”. Tesis, Sekolah Pascasarjana Universitas Islam Negeri Jakarta, 2005.

Noor, Farish, A. "The Arrival and Spread of the Tabligh Jamaah in West Papua Indonesia," RSIS Working Paper, No 191, 10 Pebruari, 2010. http/www.rsis.sg/publication/working paper/wpigi.pdf. Diakses pada 20-02-2014.

Pirzada, Abdul Khalik. Maulana Muhammad Ilyas di antara Pengikut dan Penentangnya. Terj. Masrokhan Ahmad. Yogyakarta: As-Shaf, 2003. Rahmat, Jalaluddin. Psikologi Komunikasi. Bandung: Rosdakarya, 2003.

Razak, Yusran. "Jamaah Tabligh Ajaran dan Dakwahnya." Disertasi Doktor, Sekolah Pascasarjana UIN Jakarta, 2008.

Republika, Jamaah Tabligh Gerakan Dakwah Transnasional, 12 September 2012, http/www.republika.co.id. Diakses pada 20-02-2014.

Sikand, Yoginder. "Sufisme Pembaharu Jamaah Tabligh", dalam Martin van Bruinessen dan Julia Day Howell (ed.). Urban Sufism. Jakarta: Rajawali Pers, 2008.

Uchyana, Onong. Ilmu, Teori dan Filsafat Komunikasi. Bandung: Citra Aditya Bakti, 2003.

Ya'kub, Ali Musthafa. Sejarah dan Methode Dakwah Nabi. Jakarta: Pustaka Firdaus, 1997.

Umdatul Hasanah, IAIN SMH Banten, umdahhay@yahoo.co.id 